\title{
CALLUS INDUCTION AND PLANT REGENERATION OF TOMATO (Lycopersicon esculentum CV. IPA 5) VIA ANTHER CULTURE
}

\author{
INDUÇÃO DE CALOS E REGENERAÇÃO DE PLANTAS A PARTIR DO CULTIVO \\ IN VITRO DE ANTERAS DE TOMATE (Lycopersicon esculentum CV. IPA 5)
}

\author{
Ana Christina Rabello Brasileiro ${ }^{1}$, Lilia Willadino ${ }^{2}$, Gianna Griz Carvalheira ${ }^{3}$, \\ Marcelo Guerra ${ }^{4}$
}

\section{SUMMARY}

Different growth regulators combinations were tested on the production of anther callus in tomato cultivar IPA 5. Calli were induced on media supplemented with $1.0 \mathrm{mgL}^{-1}$ gibberellic acid $\left(G A_{3}\right), 0.05 \mathrm{mLL}^{-1} \alpha$-naphthaleneacetic acid (NAA) plus $0.1 \mathrm{mg}^{-1}$ 6-benzylaminopurine (BAP), or with $1.0 \mathrm{mLL}^{-1}$ BAP plus $1.0 m g L^{-1} N A A$. The medium containing $1.0 \mathrm{mgL}^{-1} B A P$ and $1.0 m g L^{-1} N A A$ produced the highest calli frequency, and promoted plant regeneration by indirect organogenesis, when calli were transferred to $0.01 \mathrm{mgL}^{-1} \mathrm{BAP}$ and $0.001 \mathrm{mgL}^{-1} \mathrm{NAA}$ Plants regenerated presented tetraploid cells and rare diploid cells. These tetraploid plants could be used as source for further obtainment of trisomic lines, for the purpose of genic localization studies and protein compounds analysis.

Key words: growth regulators, organogenesis, tetraploid cells.

RESUMO

Diferentes combinações de reguladores de crescimento foram testadas na produção de calos a partir do cultivo de anteras de tomate cultivar IPA 5. Calos foram induzidos no meio suplementado com 1,0mgL $L^{-1}$ de ácido giberélico $\left(G A_{3}\right)+$ $0,05 \mathrm{mgL}^{-1}$ de $\alpha$-ácido naftalenoacético $(A N A)+0,1 \mathrm{mgL}^{-1}$ de 6benzilaminopurina (BAP), ou com $1,0 m g L^{-1}$ de $B A P+1,0 m g L^{-1}$ de ANA. O meio contendo $1,0 m g L^{-1}$ de BAP e 1,0mgL ${ }^{-1}$ de ANA produziu a maior freqüência de calos e promoveu a regeneração de plantas através de organogênese indireta, quando os calos foram transferidos para $0,01 \mathrm{mgL}^{-1}$ de BAP e $0,001 \mathrm{mgL}^{-1}$ de ANA. As plantas regeneradas apresentaram células tetraplóides $e$, raramente, células diplóides. Estas plantas tetraplóides podem servir como fonte para posterior obtenção de linhagens trissômicas, para serem utilizadas em estudos de localização gênica e em análises de compostos protéicos.
Palavras-chave: reguladores de crescimento, organogênese, células tetraplóides.

\section{INTRODUCTION}

Plant tissue culture techniques are recognized as useful instruments in crop improvement. Among these techniques, in vitro anther culture stands out and is an increasingly powerful tool when integrated into breeding programs (HU \& ZENG, 1984). This technique allows the acceleration of plant breeding by providing homozygous doubled haploids within a comparatively short time (NURHIDAYAH $\boldsymbol{e}$ t al., 1996). In addition, obtaining haploid plants from segregant generations facilitates genetic analysis, eliminating the complexity of the heterozygous state (MORAES-FERNANDES, 1990).

Several studies have been reported with tomato anther culture. However, the function carried out by factors such as microspore developmental stages (GULSHAN $\boldsymbol{e t}$ al., 1981; SUMMERS $\boldsymbol{e t}$ al., 1992), dark-light regimes (JARAMILLO \& SUMMERS, 1991), and growth regulators (GRESSHOFF \& DOY, 1972; ROGOZINSKA \& SKUTNIK, 1974) are still unclear.

\footnotetext{
1 Engenheiro Agrônomo, Mestre, Professor Substituto, Departamento de Biologia, Universidade Federal Rural de Pernambuco (UFRPE), 52171-950, Recife, PE. E-mail: vidal@elogica.com.br. Autor para correspondência.

${ }^{2}$ Biólogo, Doutor, Professor Adjunto, Departamento de Biologia, UFRPE. E-mail: lilia@truenet.com.br.

${ }^{3}$ Biólogo, Mestre, Professor Assistente, Departamento de Biologia, UFRPE. E-mail: carvalheira@ @etpe.com.br.

${ }^{4}$ Biólogo, PhD., Professor Adjunto, Departamento de Botânica, Universidade Federal de Pernambuco, 50732-970, Recife, PE. E-mail: mguerra@npd.ufpe.br.
} 
SHARP et al. (1971) are among the pioneers of in vitro tomato anther culture. They observed that exogenous growth regulators have no obvious effect on the induction of calli proliferation. On the other hand, GRESSHOFF \& DOY (1972) observed that differentiation of haploid calli of $\boldsymbol{L}$. esculentum can be controlled by hormones added to a defined medium. Other authors also noticed different responses to distinct dosages of growth regulators on the formation of androgenic calli (DAO \& SHAMINA, 1978; GULSHAN $\boldsymbol{e t}$ al., 1981). In a work by ZIV et al. (1982), doubled haploid plants were regenerated from non-allelic male-sterile mutants ( $\boldsymbol{m s} 10^{35}$ ), using a medium containing $0.5 \mathrm{mgL}^{-1}$ indole-3-acetic acid (IAA) and $0.25 \mathrm{mgL}^{-1}$ zeatin. Although, the regeneration of tomato plants from microspores has been strongly dependent on this mutant genotype.

The purpose of this work was to study the effect of different growth regulators on in vitro induction and growth of tomato anther calli, and their later differentiation into plants.

\section{MATERIALS AND METHODS}

Tomato plants of cultivar IPA $5(2 n=24)$ were grown in a greenhouse, watered daily and fertilized once a week. Flower buds 5 to $6 \mathrm{~mm}$ long were harvested. The developmental stage of anthers varied from the beginning of meiosis to tetrad. For cytological analysis, the anthers were fixed in Carnoy (3:1) and stained in 1\% (w/v) hematoxylin as described by FUJII \& GUERRA (1998).

The buds harvested in the morning were conditioned in a moist chamber and submitted to a cold pretreatment at $5^{\circ} \mathrm{C}$ for $6 \mathrm{~h}$, in the dark. Later, they were surface sterilized in $70 \%(\mathrm{v} / \mathrm{v})$ ethanol, for $15 \mathrm{~s}$, immersed in a $0.5 \%(\mathrm{v} / \mathrm{v})$ sodium hypochlorite solution for $5 \mathrm{~min}$ and then rinsed three times in sterile distilled water. Anthers were removed aseptically and plated on five callus induction media varying the growth regulator's composition (table 1). Basic medium, according to CAPPADOCIA \& SREE RAMULU (1980), containing MURASHIGE \& SKOOG (1962) salts (MS), myo-inositol, glycine and vitamins of NITSCH (1969) medium, 20\% $(\mathrm{w} / \mathrm{v})$ sucrose and $0.7 \%(\mathrm{w} / \mathrm{v})$ agar $(\mathrm{pH} 5.8)$ was used for all treatments. The $(10 \mathrm{~cm})$ Petri dishes used for culture were maintained in the darkness in a growth-chamber at $26 \pm 1{ }^{\circ} \mathrm{C}$ for one week and, afterwards, exposed to $16 \mathrm{~h}$ light photoperiod (90 $\left.110 \mu \mathrm{molm}^{-2} \mathrm{~s}^{-1}\right)$ provided by fluorescent illumination. The frequency of anthers producing calli was recorded after 30 and 60 days.

The calli produced were transferred to a regeneration medium composed of the same basal medium supplemented with $0.01 \mathrm{mgL}^{-1}$ 6benzylaminopurine (BAP) and $0.001 \mathrm{mgL}^{-1}$ $\alpha$-naphthaleneacetic acid (NAA). The calli with organogenic characteristics were partially fixed in formolin/ glacial acetic acid/ 50\% ethanol (5:5:90 $\mathrm{v} / \mathrm{v} / \mathrm{v})$, for posterior histological analysis, as described by JOHANSEN (1940). In order to identify the ploidy level, root tips of regenerated plants were pretreated with $0.002 \mathrm{M}$ 8 -hydroxyquinoline for $24 \mathrm{~h}$ at $10^{\circ} \mathrm{C}$, fixed in Carnoy (3:1), hydrolyzed in $5 \mathrm{~N} \mathrm{HCl}$ for $20 \mathrm{~min}$, squashed in $45 \%(\mathrm{v} / \mathrm{v})$ acetic acid and stained with $2 \%(\mathrm{v} / \mathrm{v})$ Giemsa (GUERRA, 1983).

The experiment was entirely randomized, with five treatments (six replications per treatment), where the experimental unit consisted of a Petri dish containing 25 anthers, performing 150 anthers per treatment. Statistical analyses were carried out by the ANOVA and Tukey test, at a $1 \%$ probability level, using $\sqrt{x+0.5}$ transformation.

\section{RESULTS AND DISCUSSION}

Calli formation was observed exclusively in media containing both auxins and cytokinins (1.0mgL $\mathrm{mLA}_{3}$ plus $0.05 \mathrm{mgL}^{-1}$ BAP plus $0.1 \mathrm{mgL}^{-1}$ $\mathrm{NAA}$, medium one; $1.0 \mathrm{mgL}^{-1}$ BAP plus $1.0 \mathrm{mgL}^{-1}$ NAA, medium two). A significant increment in callus production was verified as time progressed, for both media (table 2). Medium two presented the 
Table 2 - Growth regulators composition affect the average media and percentage of the number of anthers that produced calli.

\begin{tabular}{|c|c|c|c|c|}
\hline \multirow[b]{2}{*}{ Growth regulators $\left(\mathrm{mg} \mathrm{L}^{-1}\right)$} & \multicolumn{2}{|c|}{30 days } & \multicolumn{2}{|c|}{60 days } \\
\hline & Average & $\%$ & Average & $\%$ \\
\hline 1.0 BAP + 1.0 NAA (medium 2) & 4,0 a B & 16 & 16,8 a $\mathrm{A}$ & 67,2 \\
\hline $1.0 \mathrm{GA}_{3}+0.05 \mathrm{BAP}+0.1 \mathrm{NAA}($ medium 1$)$ & 2,8 a $\mathrm{B}$ & 11,2 & $6,0 \mathrm{~b} \mathrm{~A}$ & 24 \\
\hline $2.02,4 \mathrm{D}($ medium 3$)$ & $0 \mathrm{~b}$ & 0 & $0 \mathrm{c}$ & 0 \\
\hline 0.1 TIBA (medium 4) & $0 \mathrm{~b}$ & 0 & $0 \mathrm{c}$ & 0 \\
\hline 0.5 TIBA (medium 5) & $0 \mathrm{~b}$ & 0 & $0 \mathrm{c}$ & 0 \\
\hline
\end{tabular}

${ }^{1}$ Values in a column followed by different lower case or in a line followed by different capital letter are significantly different at the 0.01 probability level according to a Tukey test.

presented a pale yellow color. Green calli were also produced on the medium supplemented with $1.0 \mathrm{mgL}^{-1} \mathrm{BAP}$ and $1.0 \mathrm{mgL}^{-1}$ NAA.

Histological analysis showed that some of these calli presented tracheids, vessel elements and phloem cells initiation. Such structures were verified by GULSHAN et al. (1981) in tomato anther callus and the initiation of vessel elements was favoured by addition of NAA plus kinetin and that of the phloem in the presence of $2,4 \mathrm{D}$ plus BAP.

The calli that presented development of vascular elements

highest frequency of calli formation: $16 \%$ after 30 days and $67 \%$ after 60 days.

For some members of Solanaceae family, the inclusion in the culture medium of an auxin alone, or in combination with a cytokinin, frequently induces the formation of pollen calli (CANHOTO et al., 1990). The importance of this hormonal balance in tomato anther culture has been described by several authors. GULSHAN $\boldsymbol{e t}$ al. (1981) verified that the medium containing $2.0 \mathrm{mgL}^{-1} \mathrm{NAA}$ and $1.0 \mathrm{mgL}^{-1}$ kinetin was the most efficient for callus formation. This same auxin/ cytokinin (2/1) proportion, used in the present experiment $\left(0.1 \mathrm{mgL}^{-1}\right.$ NAA plus $0.05 \mathrm{mgL}^{-1}$ BAP) increased callus production significantly, but the highest frequency was observed in a medium supplemented with a $1 / 1$ mix of auxin/cytokinin. This result is in agreement with ROGOZINSKA \& SKUTINK (1974), who used both NAA and BAP at a concentration of $1.0 \mathrm{mgL}^{-1}$.

In this experiment, auxin in the form of 2,4 dichlorophenoxyacetic acid (2,4 D) $\left(2.0 \mathrm{mgL}^{-1}\right)$ did not stimulate callus induction. However, HENDER (1973) verified better callus development when cultivating tomato anthers in this same concentration of 2,4 D. The presence of 2,3,5 triiodobenzoic acid (TIBA) in the culture (medium four and five) did not propitiate either calli production, although this anti-auxin has been used to obtain doubled haploid maize (WILLADINO et al., 1995).

In the medium supplemented with $1.0 \mathrm{mgL}^{-1}$ $\mathrm{GA}_{3}$ plus $0.05 \mathrm{mgL}^{-1}$ BAP plus $0.1 \mathrm{mgL}^{-1} \mathrm{NAA}$, a darkening of the anthers surface was observed, although green calli were produced in about $21 \%$ of them. GRESSHOFF \& DOY (1972) also observed a similar process of calli formation, but these calli were subcultured on a medium containing $0.01 \mathrm{mgL}^{-1}$ BAP plus $0.001 \mathrm{mgL}^{-1}$ NAA, showing later organogenic potential. After five months, plant regeneration had occurred on $0,27 \%$ of the calli obtained (figure 1a). Cytological analysis showed that these plants presented tetraploid cells and rare diploid cells (figure 1b). Such differences on ploidy level can be induced by components of the culture medium, time of culture, explant source, and the plant genotype (KARP, 1988). This instability was observed by KORNNEEF $\boldsymbol{e t}$ al. (1989) in cells of plants regenerated from leaves of haploid genotypes of tomato. Of the 149 metaphase cells of root tips that were analyzed $41 \%$ were haploid, $58 \%$ diploid and $1 \%$ tetraploid. ANCORA et al. (1977), studying genotypes $L$. peruvianum, also observed that cells from one anther callus can differ in ploidy level.

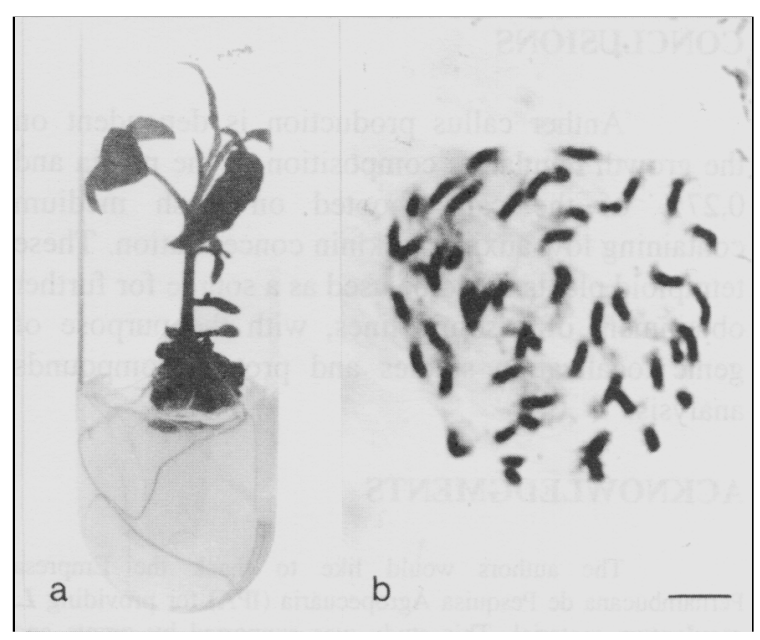

Figure 1 - (a) Regenerated plant obtained through indirect organogenesis. (b) Tetraploid cell $(2 n=4 x=48)$ of the same plant. Bar in $\boldsymbol{b}$ represents $8.1 \mathrm{~mm}$ for $\boldsymbol{a}$ and 5 um for $\boldsymbol{b}$. 
Besides the microspores, growth of somatic tissue (filament, connective, or anther wall) could be induced (WENZEL \& FOROUGHI-WEHR, 1984). LEVENKO et al. (1977) verified that anther wall cells took part in the formation of tomato mixoploid calli. CAPPADOCIA \& SREE RAMULU (1980) and ZAMIR et al. (1980; 1981) obtained plants derived from anther culture. However they were originated from somatic cells.

In anther culture, there are two pathways for plant regeneration: direct or indirect androgenesis (CANHOTO et al., 1990). Most of the plants regenerated through direct embryogenesis are haploids, while plants obtained from calli are generally diploids (CONSTANTIN, 1981).

In the present study we described the induction of anther organogenic calli, and regeneration of tomato tetraploid plants. In Oenothera hookeri De Vries, diploid plants were also obtained through indirect androgenesis (MARTINEZ \& HALAC, 1995). In Solanaceae family, as in Datura metel (IYER \& RAINA, 1972), both kinds of androgenesis, direct (embryos formation) or indirect (embryos or shoots formation), may be observed (OGURA, 1990). It appears that the type of androgenesis followed is to some extent determined by the culture medium composition and by the endogenous levels of growth regulators prevailing within anther, varying the magnitude of these influences with the species considered (CANHOTO et al., 1990). Further studies are necessary to understand the pathway by which environmental and genetical factors induce shooting from callus tissue (MARTINEZ \& HALAC, 1995).

\section{CONCLUSIONS}

Anther callus production is dependent on the growth regulators composition of the media and $0,27 \%$ of the calli shooted on fresh medium containing low auxin-cytokinin concentration. These tetraploid plants could be used as a source for further obtainment of trisomic lines, with the purpose of genic localization studies and protein compounds analysis.

\section{ACKNOWLEDGMENTS}

The authors would like to thank the Empresa Pernambucana de Pesquisa Agropecuária (IPA) for providing $\boldsymbol{L}$. esculentum material. This study was supported by grants and fellowships from Fundação de Amparo a Ciência e Tecnologia do Estado de Pernambuco (FACEPE), Conselho Nacional de Desenvolvimento Científico e Tecnológico $(\mathrm{CNPq})$ and Banco do Nordeste do Brasil (BNB).

\section{REFERENCES}

ANCORA, G., SREE RAMULU, K., DEVREUX, M. In vitro culture of anthers and stem internodes of Lycopersicon peruvianum: nuclear DNA determination in calli and cytological analysis of regenerated plants. Zeitschrift fuer Pflanzenphysiology, Stuttgart, v. 82, p. 377-388, 1977.

CANHOTO, J.M., LUDOVINA, M., GUIMARÃES, S., $\boldsymbol{e} \boldsymbol{t} \boldsymbol{a}$. In vitro induction of haploid, diploid and triploid plantlets by anther culture of Iochroma warscewiczii Regel. Plant Cell, Tissue and Organ Culture, Dordrecht, v. 21, p. 171-177, 1990.

CAPPADOCIA, M., SREE RAMULU, K. Plant regeneration from in vitro cultures of anthers and stem internodes in an interspecific hybrid, Lycopersicon esculentum $\times$ L. peruvianum. Plant Science Letters, Limerick, v. 20, p. 157-166, 1980 .

CONSTANTIN, M.J. Chromosome instability in cell and tissue cultures and regenerated plants. Environmental and Experimental Botany, Elmsford, v. 21, p. 359-368, 1981.

DAO, N.T., SHAMINA, Z.B. Cultivation of isolated tomato anthers. Soviet Plant Physiology, New York, v. 25, p. 120-126, 1978.

FUJII, M.T., GUERRA, M. Improving the hematoxylin staining method for algal cytogenetics. Biotechnique \& Histochemistry, Louisville, v. 73, n. 2, p. 78-81, 1998.

GRESSHOFF, P.M., DOY, C.H. Development and differentiation of haploid Lycopersicon esculentum (tomato). Planta, Berlin, v. 107, p. 161-170, 1972.

GUERRA, M. dos S. O uso de Giemsa na citogenética vegetal comparação entre a coloração simples e o bandeamento. Ciência e Cultura, São Paulo, v. 35, p. 190-193, 1983.

GULSHAN, T.M., VARGHESE, SHARMA, D.R. Studies on anther cultures of tomato Lycopersicon esculentum Mill. Biologia Plantarum, Prague, v. 23, n. 6, p. 414-420, 1981.

HENDER, A.B. Anther culture in the cultivated tomato, Lycopersicon esculentum. Annual Report Glasshouse Crops Research Institute, p. 130-133, 1973.

HU, H., ZENG, J.Z. Development of new varieties via anther culture. In: AMMIRATO, P.V., EVANS, D.A., SHARP, W.R., et al. (eds). Handbook of Plant Cell Culture. New York: Macmillan, 1984. v. 3. p. 65-90.

IYER, R.D., RAINA, S.K. The early ontogeny of embryoids and callus from pollen and subsequent organogenesis in anther cultures of Datura metel and rice. Planta, Berlin, v. 104, p. 146-156, 1972.

JARAMILLO, J., SUMMERS, W.L. Dark-light treatments influence induction of tomato anther callus. HortScience, Alexandria, v. 26, n. 7, p. 915-916, 1991.

JOHANSEN, W.A. Plant microtechnique. New York: MacGraw Hill, 1940. 523 p.

KARP, A. Origins and causes of chromosome instability in plant tissue culture and regeneration. In: BRANDHAM, P.E. (ed). Kew Chromosome Conference III, HMSO. Kew: Royal Botanic Gardens, 1988. p. 185-192. 
KOORNNEEF, M., DIEPEN, J. van, HANHART, C.J., $\boldsymbol{e} \boldsymbol{t}$ al. Chromosomal instability in cell and tissue cultures of tomato haploids and diploids. Euphytica, Dordrecht, v. 43, n. 1/2, p. 179-186, 1989.

LEVENKO, B.A., KUNAKH, V.A., YURKOVA, G.N. Studies on callus tissue from anthers. I. Tomato. Phytomorphology, Delhi, v. 27, n. 4, p. 377-383, 1977.

MARTINEZ, L.D, HALAC, I.N. de. Organogenesis of antherderived calluses in long-term cultures of Oenothera hookeri de Vries. Plant Cell, Tissue and Organ Culture, Dordrecht, v. 42, p. 91-96, 1995.

MORAES-FERNANDES, M.I.B de. Obtenção de plantas haplóides através da cultura da anteras. In: TORRES, A.C. CALDAS, L.S (eds). Técnicas e aplicações da cultura de tecidos de plantas. Brasília: EMBRAPA, Centro Nacional de Pesquisas de Hortaliças, 1990. p. 311-332.

MURASHIGE, T., SKOOG, F. A revised medium for rapid growth and bioassays with tobacco tissue culture. Physiologia Plantarum, Copenhagen, v. 15, p. 473-497, 1962

NITSCH, J.P. Experimental androgenesis in Nicotiana. Phytomorphology, Delhi, v. 19, p. 389-404, 1969.

NURHIDAYAH, T., HORN, R., RÖCHER, T., et al. High regeneration rates in anther culture of interspecific sunflower hybrids. Plant Cell Reports, Berlin, v. 16, p. 167-173, 1996.

OGURA, H. Chromosome variation in plant tissue culture. In: BAJAJ, Y.P.S. Somaclonal variation in crop improvement I. Berlin: Springer-Verlag, 1990, p. 49-84. Biotechnology in Agriculture and Forestry, 11.
ROGOZINSKA, J.H., SKUTNIK, L. Effects of auxins and cytokinins on tomato callus from anthers. Acta Societatis Botanicorum Poloniae, Warsaw, v. 43, n. 1, p. 81-92, 1974.

SHARP, W.R., DOUGALL, D.K., PADDOCK, E.F. Haploids plantlets and callus from immature pollen grains of Nicotiana and Lycopersicon. Bulletin of the Torrey Botanical Club, New York, v. 98, p. 219-222, 1971.

SUMMERS, W.L., JARAMILLO, J., BAILEY, T. Microspore developmental stage and anther length influence the induction of tomato anther callus. HortScience, Alexandria, v. 27, p. 838-840, 1992.

WENZEL, G., FOROUGHI-WEHR, B. Anther culture of cereals and grasses. In: VASIL, I. K. (ed) Cell culture and somatic cell genetics of plants. London: Academic Press, 1984. v. 1, p. 311-327.

WILlADINO, L, CAMARA, T.R., SANTOS, M.A., et al. Obtenção de uma linhagem de milho tolerante ao estresse salino mediante a cultura de anteras. Pesquisa Agropecuária Brasileira, Brasília, v. 30, n. 11, p. 1313-1318, 1995.

ZAMIR, D., JONES, R.A., KEDAR, N. Anther culture of malesterile tomato (Lycopersicon esculentum Mill.) mutants. Plant Science Letters, Limerick, v. 17, p. 353-361, 1980.

ZAMIR, D., TANKSLEY, S.D., JONES, R.A. Genetic analysis of the origin of plants regenerated from anther tissues of Lycopersicon esculentum Mill. Plant Science Letters, Limerick, v. 21, p. 223-227, 1981.

ZIV, M., HADARY, D., KEDAR, N. Dihaploid plants regenerated from tomato anthers in vitro. Plant Tissue Culture. Proceedings 5th International Congress of Plant Tissue \& Cell Culture. p. 549-550, 1982.

Ciência Rural, v. 29, n. 4, 1999. 